\title{
Invasive plant species and the consequences of its prevalence in biodiversity
}

\author{
Ivan Shuvar ${ }^{1}$, Hanna Korpita $^{2}$, Antin Shuvar ${ }^{3}$, Bogdan Shuvar $^{4}$ and Ruslan Kropyvnytskyi ${ }^{5}$ \\ ${ }^{1}$ Department of Plant Technology, Lviv National Agrarian University, 80381, V. Velykoho 1, Dublyany, Ukraine. \\ ${ }^{2}$ Department of Genetics, Selection and Plant Protection, Lviv National Agrarian University,80381, V. Velykoho 1, Dublyany, Ukraine. \\ ${ }^{3}$ Department of Crop Production Institute of Agriculture of the Carpathian Region NAAS, 81115, Hrushevskogo Str 5,. Oboroshino \\ village, Pustomytivskii district, Lvivska region.Ukraine. \\ ${ }^{4}$ Department of entrepreneurship, trade and stock-taking activities, Lviv National Agrarian University, 80381, V. Velykoho1, Dublyany, \\ Ukraine. \\ ${ }^{5}$ Department of soil science and agriculture, Polissia National University . 10002, Old Boulvar 7, Zhytomyr, Ukraine.
}

\begin{abstract}
The problem of weed control has been facing mankind since the beginning of agricultural development, and is especially relevant today. In recent decades, the problem of invasion of rare plant species in Ukraine has been growing. Surveying areas, developing and implementing measures to prevent the destructive effects of biodiversity should be a priority for the preservation of natural ecosystems and environmental protection.
\end{abstract}

\section{Introduction}

Invasive alien species are plants that accidentally or demonstratively enter the natural environment, where they are not usually found, with a significant negative impact on the new environment. The ecological cost of invasions is irreparable damage to species and ecosystems. Experts studying this problem believe that invasive alien species cause significant direct economic damage worldwide, which is converted into billions of dollars annually [11, 12 - 14, 17, 20 - 22].

By the end of the twentieth century, the negative impact of non-native organisms on flora, fauna and even society has reached such proportions that it has attracted the attention of many experts from state and international institutions. The importance of this issue has been on the agenda of international biodiversity forums: the United Nations Conference on Sustainable Development (Rio de Janeiro, Brazil, 1992) and the United Nations Conference on Non-Aboriginal Species (Trondheim, Norway, 1996), as well as at numerous special forums on phytoinvasions: "Biological pollution: the control and impact of invasive exotic species" (1993), "Harmful non-indigenous species in the United States" (1993), "Plant Invasions. General aspects and special problems" (1995), "International conference on the ecology of invasive alien plants" (1997), "Biological invasions of ecosystems by pests and beneficial organisms" (1997), "Plant invasions: studies from North America and Europe" (1997) etc.

\subsection{Damage to biodiversity}

Mass migration of plants, especially invasive species, causes some changes in ecosystems. It is known that each species plays a role in a complex chain of relationships between the components of individual parts of biocenoses and the biosphere as a whole. Changing this role (suppression or reduction of populations due to the total impact of adventitious plant species or one of them) leads to certain changes at all levels. The introduction of adventitious species into groups, the structure of which is already disrupted due to the influence of one or more factors, can cause significant and irreversible changes. The penetration of invasive species causes a redistribution of species in groups. This process disrupts the historically formed ecological balance and leads to the loss of representativeness of the respective flora complexes.

Invasive species can affect even the complete extinction of native species due to competitive exclusion, niche relocation or hybridization with related species. Therefore, in addition to their economic consequences, such invasions can lead to significant changes in the structure, composition and global distribution of biota, the introduction of which will lead to the homogenization of fauna and flora in the world and the loss of biodiversity. Therefore, concern for the impact of invasive species on biodiversity should be based on actual monitoring results and take into account environmental and economic challenges regarding potential risk. 


\subsection{Impact on genetic pollution}

Native plant species can be threatened and endangered by genetic contamination. Genetic contamination is an unintentional hybridization that results in the homogenization or replacement of local genotypes that change species. Genetic contamination occurs either through introduction or habitat modification, when previously isolated species come into contact with new genotypes. It is established that new species adapt to their new conditions in a very short period of time. The population size of invasive species may be small over the years and then a possible explosion in the population (a phenomenon known as the "delay effect").

Experts believe that an approximate estimate of the rate of spread of invasive plants: $>100 \mathrm{~m}$ over a period of $<50$ years for taxa propagated by seeds; $>6 \mathrm{~m}$ in 3 years - for vegetatively distributed taxa. For dioecious plants that have seed reproduction, the establishment of the fact of spread is possible only after the entry of individuals of both sexes.

In Ukraine, the impact of non-native plants on the environment is growing every year. In terms of the level of Adventization of flora, Ukraine ranks quite high among other flora in the world. Currently, the spontaneous fraction of adventive flora of Ukraine has about 830 species of vascular plants (of which about 50 species are dangerous invasive), which is about $14 \%$ of the total species of flora of the country, which has more than 6,000 species of vascular plants, including all aboriginal and adventive species, as well as the main cultivated and wild plants (Mosyakin, 1996). For comparison: the adventitious fractions of the flora of Western Europe are $13-18 \%$, Japan - 14\%, the United States - 29\%, Australia $-11 \%$, and the adventitious flora of the islands reach even $73 \%$. According to generalized data, the average percentage of adventive species is $16 \%$, with $11 \%$ on the mainland and $31 \%$ on the islands (Mirkin and Naumova, 2011), and the process of adventitia of the flora continues to progress.

A prominent place is occupied by species, the distribution of which is in the nature of expansion. They are characterized by stress tolerance, a high degree of naturalization, effective means and rapid spread, high coenotic activity, wide ecological amplitude. Over the last 150 years, 29 species of adventive plants have become widespread in Ukraine. As a result, there is currently no flora complex in the flora of Ukraine in which invasive species do not participate. Since the end of the twentieth century. more and more plants that are in a state of expansion, replenish the group of agriophytes. At the same time, the period of passing the lower (primary) stages of naturalization is decreasing.

Adventive plants on the impact on the ecosystem (according to the classification of J. Falinski, 1997) are divided into three categories:

1) species that have achieved biogeographical success, ie captured similar, mostly anthropogenically transformed habitats with weakened competition (such species are characterized by stable expansion of the range);

2) species that have achieved biocoenotic (phytocoenotic) success (there are about 100 such species in Ukraine, but they pose a significant danger, much greater than the previous category, as they are able to enter existing natural groups and have an impact on their structure, dynamics and functions, self-regenerate and form stable populations; between them and local species there is competition for habitat and role in the structure of cenoses; these species cause adventitization of natural flora complexes);

3) species that have achieved genetic success, ie adapted to new living conditions by changing life strategy, hybridization with related species, mutations, genetic-automatic processes, etc. (Such species are relatively few, but they have a high chance of consolidation in the flora - primarily Centaurea diffusa Lam., Xanthium albinum (Widder) H. Scholtz, etc.) $[1-4,11-15,22-29]$.

The spread of invasive species causes ecosystem degradation and fragmentation. These processes are identified as the world's greatest threats to nature and key causes of species extinction.

Ecosystem degradation and fragmentation are related processes. They usually occur simultaneously. In some scientific papers, fragmentation is defined as the loss and isolation of habitats. However, these two processes are different.

Ecosystem degradation refers to the disappearance of an ecosystem, or the collection of organisms and the physical environment in which they exchange energy and substances. However, in many studies it has been considered for the habitat of a particular organism. Habitat loss is a change in the natural environment of a species in which the properties of the environment no longer meet the conditions of its survival. Such changes usually begin with a process in which the quality of the environment deteriorates. If the quality of the environment declines so much that it can no longer meet the needs of the species, it is called "habitat loss".

Fragmentation is usually defined as the result of ecosystem degradation and most often takes the form of a once integral landscape divided into small parts. Ultimately, fragmentation reduces the integrity and affects the distribution and migration of species, thus isolating their populations and disrupting the distribution of plants and animals (and their genetic material) in the landscape.

Thus, the adventitia of the flora of Ukraine is progressively developing and significantly affects the environment at all levels (population, species, coenotic and ecosystem) and is characterized by the following features:

* increase in the number of adventive species, their permanent component, species with a high degree of naturalization;

* the composition of adventitious flora is represented by almost 100 invasive species; 
* the composition of the unstable component becomes more diverse in origin; therefore, the conditions for naturalization of adventitious plants are more favorable;

* significant stability of adventitious species populations has been revealed due to the increase in their size in the process of merging of separate, previously separated, colonies, which increases the risk of possible gene exchange between them;

* the formation of new ecotypes, morphophysiological forms, mutants, hybrids was registered, which also enhances the adaptive capacity of adventitious plants;

* habitat compaction due to the expansion of the ecological spectrum of ecotopes suitable for rooting of adventitious plants, which, on the one hand, indicates the deterioration of vegetation, and on the other - the accumulation over time of adaptive capacity of invasive species.

\section{Materials and Methods}

\subsection{Object of study}

The object of research - species of invasive plants in the natural, semi-natural, ruderal and plant groups of vegetation distributed in their territory of the western forest-steppe of Ukraine.

The research was performed (2007-2020) in accordance with existing methods, collected herbariums and analytical processing of literature sources of other authors, including on individual taxa, their morphological, ecological and other features (Abduloeva and others, 2009; Bagrikova, 2013; Klimuk et al., 2006; Kovalenko, 2016; Kolomiychuk, 2013; Krichfalushi et al., 2001; Lukash, 2008; Nechitaylo et al., 2002; Novosad et al., 2009, 2013; Orlov et al., 2016; Panchenko, 2005; Sicak, 2015; Solomakha et al., 2004; Tarasov, 2012; Weaver, 1999; Chorney et al., 2005; Tokaryuk et al., 2012 and others.).

\section{Results}

The results of the research reflect the current state of phytoinvasions in the western forest-steppe of Ukraine and can serve as a warning about potentially dangerous species and as a basis for monitoring invasive plant species (primarily, monitoring the spread and determining the impact at different levels (species, coenotic, ecosystem) for facilities, regions, natural areas, etc., in order to further develop effective measures for their control and management.

According to observations, it was found that among foreign plants in the western forest-steppe of Ukraine most often began to appear and attract the attention of A. artemisiifolia L., species of the genera Impatiens L., Heracleum L. and Solidago L., etc., which are mostly in a state of expansion or approaching it (table).

Table. Invasive plant species common in the western forest-steppe of Ukraine (according to the results of the survey of territories, 2019-2020)

\begin{tabular}{|l|l|l|l|}
\hline \multicolumn{1}{|c|}{ Name of the species } & \multicolumn{1}{c|}{ Origin } & \multicolumn{1}{c|}{ Hygromorph } \\
\hline Amaranthus retroflexus $\boldsymbol{L}$. & North American & Annual & Xero-mesophyte \\
\hline Ambrosia artemisiifolia L. & North American & Annual & Xero-mesophyte \\
\hline Asclepias syriaca L. & North American & Perennial & Xero-mesophyte \\
\hline Bidens frondosa & North American & Annual & Mesophyte \\
\hline Conyza canadensis & North American & Annual & Mesoxerophyte \\
\hline Echinocystis lobata & North American & Annual & Mesophyte \\
\hline Helianthus tuberosus & North American & Perennial & Xero-mesophyte \\
\hline Heracleum mantegazzianum & Caucasian & Biennial, Perennial & Mesophyte \\
\hline Heracleum sosnowskyi & Caucasian & Biennial, Perennial & Mesophyte \\
\hline Hordeum murinum L. & North African & Annual & Mesophyte \\
\hline Impatiens glandulifera & East Asian & Annual & Mesophyte \\
\hline Impatiens parviflora & Central Asian & Annual & Mesophyte \\
\hline Iva xanthiifolia & North American & Annual & Xero-mesophyte \\
\hline Lepidotheca suaveolens & North American & Annual & Mesophyte \\
\hline Lupinus polyphyllus & North American & Biennial & Mesophyte \\
\hline Oenothetra rubricaulis & North American & Biennial & Mesoxerophyte \\
\hline
\end{tabular}




\begin{tabular}{|l|l|l|l|}
\hline Phalacroloma annuum & North American & Annual & Mesophyte \\
\hline Phytolaccae americanae & North American & Perennial & Mesophyte \\
\hline Solidago canadensis & North American & Perennial & Xero-mesophyte \\
\hline Vicia villosa & Mediterranean & Annual & Xero-mesophyte \\
\hline Xanthium albinum (Widd.) H. Scholz & Middle European & Annual & Xero-mesophyte \\
\hline Xanthoxalis dillenii & North American & Perennial & Xero-mesophyte \\
\hline
\end{tabular}

\section{Discussion}

The negative consequences of the spread of invasive plant species, first of all, are manifested in changes in the structure of flora, flora complexes and plant communities, in the large-scale impact on ecosystems and individual species. The following consequences cause:

$>$ increasing competition for distribution in transformed ecotopes in favor of adventitious species, which are less demanding of growing conditions than aboriginal, especially rare species;

$>$ insularization of populations of aboriginal species;

$>$ suppression of aboriginal species by more competitive invasive species;

$>$ clogging of the gene pool of related aboriginal species in the process of hybridization with adventive;

$>$ redistribution of species according to their role in groups, which violates the ecological balance and may lead to loss of representativeness of the relevant flora complexes;

$>$ changes in food chains;

$>$ disturbance of ecosystems, as evidenced by patterns in the distribution of species in zonal, regional, ecological and coenotic aspects, the relationship between stable and unstable components of adventive flora;

$>$ cumulative impact of adventitious species often reaches the level of local or regional environmental crisis or catastrophe $[1-15,22-26]$.

\section{Conclusions}

In order to reduce the threat of invasive plants, we propose to develop a comprehensive program for the study of invasive processes in natural and cultural phytocenoses of Ukraine, which is aimed at carrying out a set of priority research, including:

a) introduction and maintenance of a register of invasive plant species to determine the degree of threat to individual regions;

b) creation of a system for monitoring invasive plant species in forest, meadow and other types of phytocenoses to determine the rate of invasion of individual species;

c) developing strategies to prevent, manage, and reduce the risks associated with invasive plant species in agriculture and forestry in the context of global climate change;

d) elucidation of the economic, social and environmental consequences of the expansion of invasive plant species;

f) strengthening coordination and exchange of information between researchers (in Ukraine and internationally), users of natural plant resources and regulatory authorities on integrated approaches to the management of invasive processes and their prevention.

\section{Referenses}

1. C.C. Daehler, D.A. Carino, Biol. Invasions, 2, 93-102 (2000)

2. V.P. Gudz, I.D. Primak, S.P. Tanchik, I.A. Shuvar, Agriculture (2014)

3. I.A. Shuvar, V.P. Gudz, A.A.Yunik, H.M. Korpita, Herbological atlas-reference book of Ukraine (2020)

4. I. Shuvar, H. Korpita, A. Yunyk, Productivity of ferocious barley and cartopean in achrocenoses of the western foreststeppe of Ukraine (2019)

5. I. Shuvar, H. Korpita, Agribusiness. Reduce weediness, 3(62), 40-42 (2020)

6. I. Shuvar, H. Korpita, Instytut zemlerobstva NAAN, 71, 3-4 (2016)

7. I. Shuvar, H. Korpita, "ScienceRise", 9/1 (26), 39 (2016)

8. I. Shuvar, H. Korpita, V. Balkovskyi, A. Shuvar, E3S Web of Conferences, 254, 02016 (2021)

9. I. Shuvar, V. Gudz, A. Shuvar, O. Krushynskyy, Ecological and herbological monitoring and forecast in agrocenoses (2011)

10. O.O. Ivashchenko, Weeds in agrophytocenoses (2001) 
11. O.O. Ivashchenko, General herbology: monograph. NAAS, Institute of Bioenergy Crops and Sugar Beets, Institute of Plant Protection NAAS (2019)

12. D. Jones, et al., Biol. Invasions. 20, 2091-2105 (2018)

13. Bakacsy László, Bagi István, Survival and regeneration ability of clonal common milkweed (Asclepias syriaca L.) after a single herbicide treatment in natural open sand grasslands. 10, 14222 (2020)

14. B.M. Mirkin, L.H. Naumova A short course in general ecology. Part II: Ecology of ecosystems and biosphere (Ufa: BSPU Publishing House, 2011)

15. C.E. Mitchell, A.G. Power, Nature, 421, 625-627(2003)

16. S.L. Mosyakin, Ukr. botan. magazine, 53 (5), 536-545 (1996)

17. Novyye problemnyye vidy sornyakov - Vatochnik siriyskiy, URL: https:/www.zerno-ua.com/journals/2010/noyabr2010-god/novye-problemnye-vidy-sornyakov-vatochnik-siriyskiy/

18. Z. Paukova, V. Kaderova, L. Bakay, Agriculture, 59(4), 161-166 (2013)

19. V. Protopopova, M. Shevera, Modern state of phytoinvasions in Ukraine. International Conf. on the ecology of invasive alien plants (Maddalena, 13-16 October, 1997)

20. P. Pyiek, D. Richardson, In Biological invasions (Springer, Berlin 2007)

21. K. Reinhart, A. Packer, V.D. Putten, Ecol. Lett. 6, 1046-1050 (2003)

22. I. Shuvar, I. Boyko Naukovyy visnyk NUBiP Ukrayiny, 162, 27-34 (2011)

23. Shuvar I., Korpita H., Folia pomeranae universitatis technologiae stetinensis., 355 (54 )2, 31-38 (2020)

24. Shuvar I., Korpita H. Innovative technologies in crop production IV All-Ukrainian Scientific Internet Conference. Asclepias syriaca captures the fields of Ukraine, 173-175

25. Shuvar I., Korpita H. Achievements of Ukraine and the EU in ecology, biology, chemistry, geography and agricultural sciences, URL: https://doi.org/10.30525/978-9934-26-086-5-52.

26. Shuvar I.A. and others, Ecological and herbological monitoring and forecast in agrocenoses (2011).

27. Shuvar I.A. Ahrobiznes sohodni, 24-27 (2013).

28. Shuvar I.A., Gudz V.P., Shuvar A.I., Particularly dangerous plants of Ukraine (2013).

29. Shuvar I.A., Shuvar A.I., Boyko I.E. and others, Silskyy hospodar, 1/2, 28-32 (2013).

30. T.G. Stohlgren, D.T. Barnett, J.T. Kartesz, Front. Ecol. Environ, 1, 11-14 (2003) 